\title{
A totally new digital 3D approach for reassembling fractured archaeological potteries using thickness measurements
}

\author{
Michail I. Stamatopoulos ${ }^{2}$, Christos-Nikolaos Anagnostopoulos ${ }^{1}$ \\ ${ }^{1}$ Social Sciences School, Cultural Technology and Communication Dpt., University of the Aegean, Lesvos isl., Mytilene, 81100, Greece \\ ${ }^{2}$ School of Science and Technology, Computer Science Dpt., Hellenic Open University, Patra, 26335, Greece
}

\begin{abstract}
The reassembly of broken archaeological ceramic pottery from its fragments (called sherds or ostraca) is an open and complex problem, which remains a scientific process of extreme interest for the archaeological community. All the solutions suggested by various research groups and universities so far, depend on external information such as the outline of sherds, some geometric characteristics, the matching of the discontinued surfaces due to fracture, the cusps and corners of sherds, etc. In our approach, the reassembly process is based on a different and quite fail-safe idea, since it focuses on thickness information encapsulated in the inner part of the sherds, which is not -or at least not heavily- affected by harsh environmental conditions and is safely kept within the sherd itself. The method is being verified in various case experiments, using cutting-edge technologies and precise measurements on 3D models.
\end{abstract}

\section{Section: RESEARCH PAPER}

Keywords: thickness profile; pottery reassembly; photogrammetry; 3D acquisition

Citation: Michail I. Stamatopoulos, Christos-Nikolaos Anagnostopoulos, A totally new digital 3D approach for reassembling fractured archaeological potteries using thickness measurements, Acta IMEKO, vol. 6, no. 3, article 4, September 2017, identifier: IMEKO-ACTA-06 (2017)-03-04

Section Editor: Sabrina Grassini, Politecnico di Torino, Italy

Received February 14, 2017; In final form July 31, 2017; Published September 2017

Copyright: (C) 2017 IMEKO. This is an open-access article distributed under the terms of the Creative Commons Attribution 3.0 License, which permits unrestricted use, distribution, and reproduction in any medium, provided the original author and source are credited

Corresponding author: Christos-Nikolaos Anagnostopoulos, e-mail: canag@aegean.gr

\section{INTRODUCTION}

In every archaeological excavation, a variety of small ceramic pottery fragments (called sherds or ostraca) are revealed, which provide valuable data that will be used by archaeologists as a time stamp for the excavation itself. The nature of these small objects (due to the four elements, soil, water, heat and air) give them some special properties and make them highly resistant to time and wear. Moreover, sherds are not stolen, they remain at the place where the ceramic pottery was destroyed and like little papyri, they carry unique undeleted information over the centuries.

The quantity and high value of such information rightly gives to sherds the title of best data carrier from ancient times to our days.

\section{RELATED WORK}

For the reassembly of a ceramic pottery, the majority of the scientific methods suggested by various research groups and universities so far, depend on external information such as the outline of sherds, some geometric characteristics, the matching of the broken surfaces, the geodesic distances, their cusps and corners of sherds, the axis of symmetry, the colours or even on the theme portrayed on it [1]-[14].

All these methods suffer from problems caused by external wear and decay of the material during the exposure in soil. As a result, many characteristics on the surface of the sherds have been altered due to long exposure over time, leading most research methods based on external characteristics, to weak results [15]-[17]. Therefore, it is no surprise that, to our knowledge and after extensive search in museum laboratories in countries of high archaeological interest (Greece, Italy, Vatican and Egypt), an automatic method that works effectively to restore a real ancient theme is not available. In contrast, the process is performed manually by field experts, who align fragments by minimizing the distance between their adjacent regions while simultaneously trying to ensure geometric continuity across them (if possible). 


\section{THE THICKNESS PROFILE METHOD (TP)}

The suggested methodology is based on a new approach that can be considered scientifically more effective than others, as we seek important information encapsulated inside the core of the sherd and not on its surface. Our approach works even if some of the sherds are missing, it is not affected neither by external wear and damages, nor by the geometrical shapes and colour degradation of the pottery. The new method is based on exploration, extraction and utilization of all possible thickness information (i.e. Thickness Profile) which may have encapsulated inside each sherd. All this information, as a sequence of numbers, can be sorted, compared and provide a complete and efficient solution for the complex problem of reconstruction, reassembling, restoration and recovery of an ancient broken ceramic pottery which is fragmented into pieces of random sizes and shapes. The main idea is based on the fact that as the potter rotates the pliable clay on the wheel to create the pottery, he creates distinguishing rings with different thicknesses which are unaltered and they can easily be detected. The gradual construction of a pottery on a wheel starts from the base, continues up to the main body and usually ends at the neck and the rim [18]. This gradual upward movement of the artist's hands in the clay body generates a certain thickness profile which can be detected as it varies, with absolute certainty, from point to point, from height to height and of course from pottery to pottery. This distinction generates the image of a structure, which resembles a stack of horizontal rings with specific thickness in relation to the pottery height. Specifically, as the potter's fingers push outwards (expansion of the clay body), the clay in these points gets thinner, while in the case of inward pressure (contraction of the clay body) the clay gets thicker. Based on the above, it is reasonable to consider that each sherd can theoretically fit to a specific point of the stack of rings and hence to a corresponding point in the overall thickness profile or a specific thickness contour of a particular pottery. The new suggested methodology comprises of three basic steps, namely: i) the appropriate orientation (Figure 1) and 3D scanning (Figure 3a) of each fragment, ii) the extraction of their optimal thickness profile (TP) as an intersection of the 3D model with a properly oriented vertical plane (Figure $3 \mathrm{~b}$ and Figure $3 \mathrm{c}$ ) and iii) the repetitive process for maximizing matching results between TPs in order to achieve a locally optimal alignment between possibly neighbouring sherds (Figures 5d, 5e and 5f).

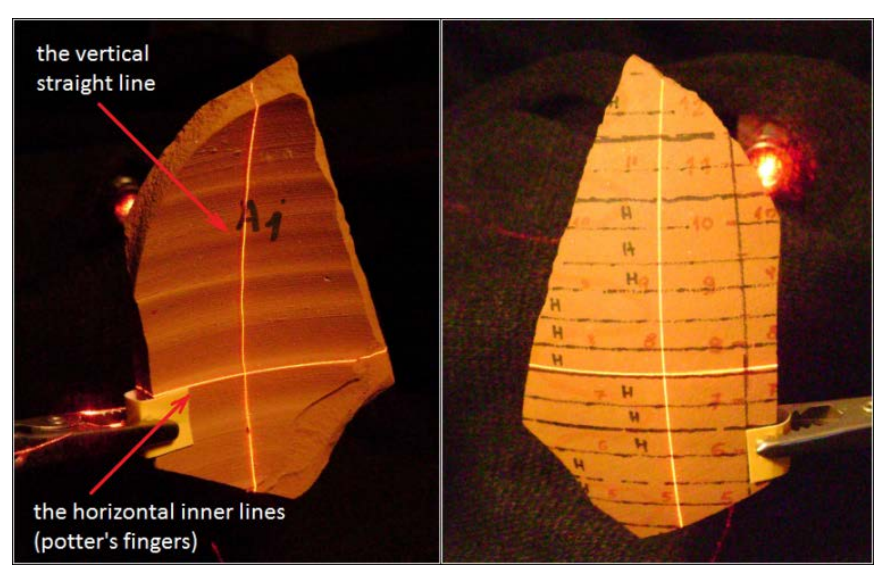

Figure 1. The orientation procedure applied on a sherd between two crosshair beam lasers (left and right, back and front view respectively).

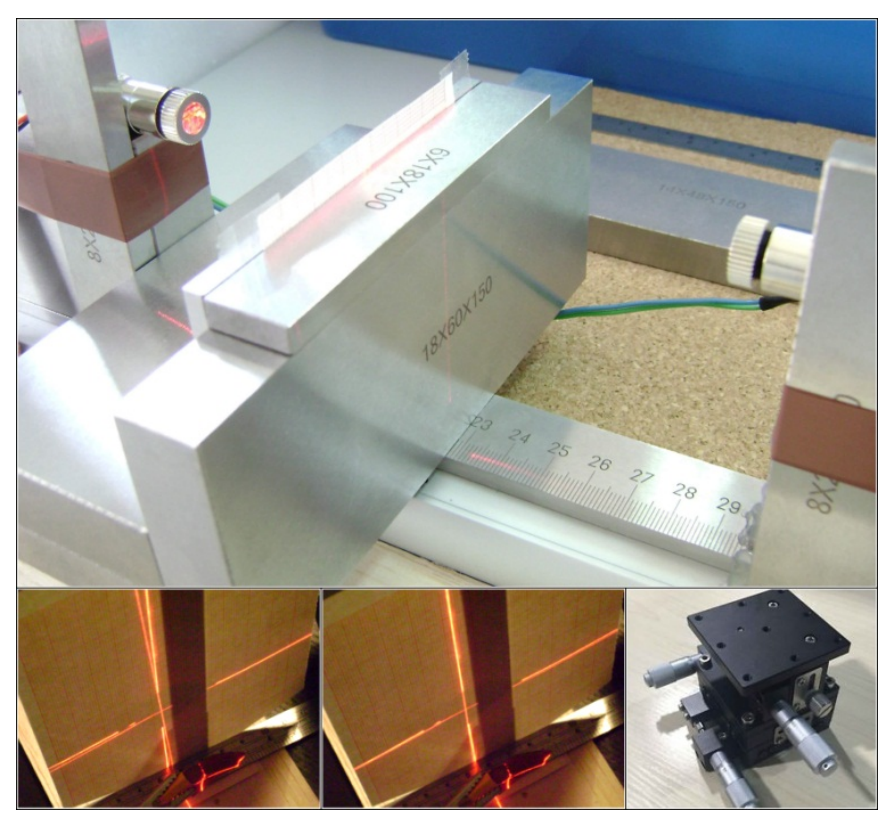

Figure 2. Our special equipment.

\subsection{Creation of 3D models (point clouds)}

As it is absolutely necessary for the archaeologists, to obtain the appropriate profile measurements without damaging the sherds, our method is implemented and validated using their digital 3D models, making the extraction of measurements fully exploitable without influencing the sherd itself. Initially, on each sherd we choose and draw a specific vertical straight line (Figure 1) through which we expect to extract the largest possible thickness profile. For the process we use some special crosshair beam lasers (Figure 2 bottom-left) and a special stable XYZ positioning platform (Figure 2 bottom-right). Each sherd is then placed on a stable basis and is panoramically photographed at close distance, from all sides and various angles (Figure 3a). The result is a set of 30-50 photos for each sherd, which is transformed into a digital 3D model (point clouds or mesh) using a specialized photogrammetry software (Figure 3b).

\subsection{Thickness profile extraction}

It is very important for each sherd, to detect the ideal vertical plane providing the richest information concerning thickness. The longest vertical plane to the horizontal rings is selected so that it allows the extraction of the maximum possible thickness profile (Figure 3c). This is especially important, since the largest possible thickness profile for each sherd is needed, in order to perform the optimum thickness matching result between neighbouring sherds. This vertical plane is absolutely oriented to be perpendicular to the horizontal inner lines of the sherd and using an appropriate 3D modelling software, the TP of the sherd is calculated with high precision. For the calculation, we perform thickness sampling every one millimeter (Figure $3 \mathrm{~d}$ and $3 \mathrm{e}$ ).

\subsection{Thickness profile matching}

Following the previous steps, by sliding small thickness profiles along on larger ones (Figure 5e) until we obtain the optimal fit, the method retrieves candidate matches between sherds performing local score optimization (Figure $5 \mathrm{~d}$ ). The Thickness Profile method is a semi-automatic method as, in the case of two adjacent sherds, it cannot decide which one will be 


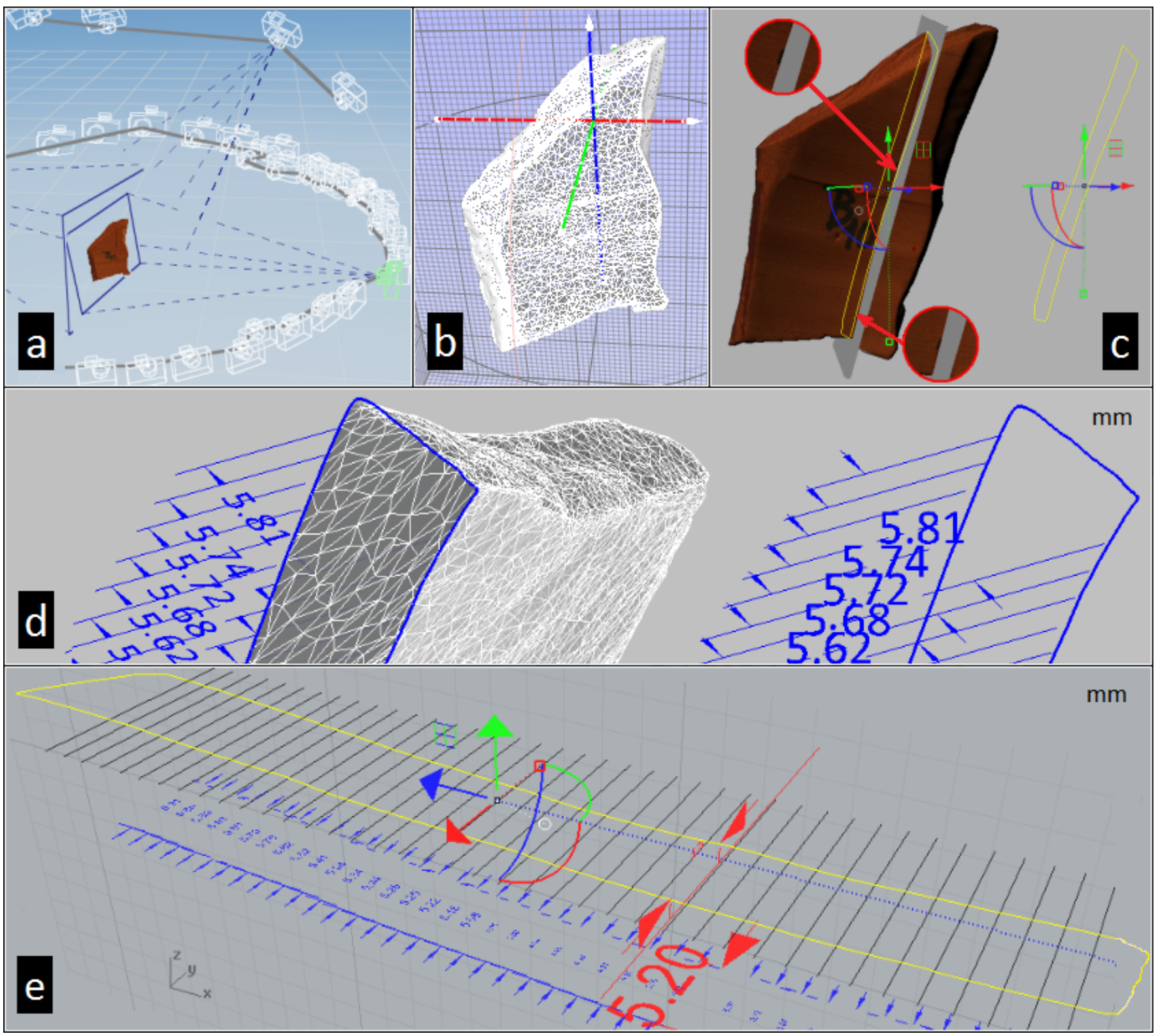

Figure 3. The photogrammetric process, the 3D model and the thickness profile (TP) acquisition.

placed left and which will be placed right. At this point, the expert eye of the archaeologist/user, should give the correct arrangement (left or right). In addition, small sherds, usually, do not have the ability of providing adequate thickness information and therefore they can raise the chances of giving misleading arrangement. For these reasons, the process is followed in stages, starting from the largest available sherd and moving gradually to the smaller ones. Starting from a master sherd, the main task is to aggregate progressively more and more thickness information (Figure $5 \mathrm{f}$ ), thus create a longer thickness profile, increasing the chances to match up the remaining sherds in the right place. Hence, at the beginning of the process, the largest available sherd is assigned with the role of the "driver" (master sherd) and as the process is being followed, when two or more pieces are matched together, a single meta-sherd with an aggregate thickness profile is formed (Figure 5c). Intuitively, this corresponds to virtually gluing sherds together, while the TPs of the already matched parts become a sort of "common values" to the TP of the meta- sherd. This approach ensures that those TPs which have been previously matched in some pair of sherds are no longer considered for future pairing. Our matching procedure is like having smaller thickness profiles gliding along on larger ones. The ideal matching could be obtained only if the number sequence referring to the TP of a small sherd could perfectly match up with part of or the entire number sequence referring to the TP of a large sherd. The ideal matching would be feasible only in an ideal case and not with real data (due to noise). Besides, our method is based more on the plethora of measurements than on the high accuracy of measurements. The TP method is actually looking for the best "score", which means: the fewer differences in the most possible comparisons.

In terms of maths, the best "score" is defined as the sum of the absolute differences among the most possible comparisons between two sherd profiles (Figure 5d). The Thickness Profile method works better with pottery that were built in late archaeological periods (Archaic, Classical and Hellenistic) since these pottery were manufactured using improved "technology" 
(better wheels, clay quality, best cook, etc.). As a result, they have characteristics that make them more sophisticated and can provide better thickness information which, in turn, can be easily exploited through our method.

\section{EXPERIMENTAL VALIDATION}

Using handmade replicas of ceramic pottery we demonstrate in this section the accuracy and efficiency of the suggested method. A handmade ceramic replica (Figure 4) is intentionally broken and the 34 useful resulting sherds are digitally reassembled through the Thickness Profile method. Before smashing the pottery, a set of horizontal and vertical lines is marked on the pottery surface and will be later used to confirm the rightness of our method. In particular, the pottery was placed on a horizontal surface and circular concentric contours were drawn on it, at a $0.5 \mathrm{~cm}$ interval. Likewise the outer surface is partitioned into eight different vertical areas (namely, A, B, C, D, E, F, G and H) tracing vertical lines at horizontal angles of 45, 90, 135, 180, 225, 270, 315 and 360 degrees. The correctness of the marking procedure was verified by lighting up a vertical laser beam along the outer surface of the pottery at the above mentioned angles.

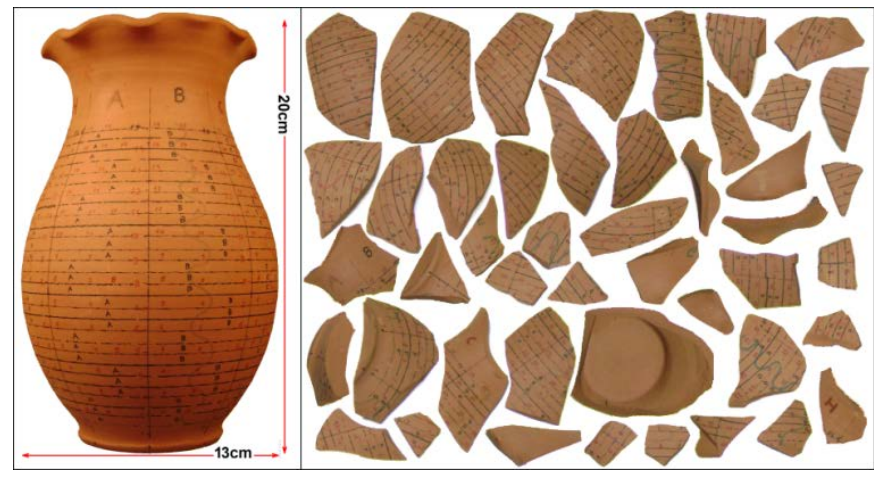

Figure 4 . The pottery replica and the 46 sherds after intentional breakage.

\subsection{Demonstration of the efficiency of the TP method}

For the sake of simplicity, we hereby demonstrate the efficiency of Thickness Profile method using five known neighbouring sherds (A4, A5, B10, C2 and C15) of the specific pottery. Figure $5 \mathrm{a}$, displays the acquired $3 \mathrm{D}$ models from these five fragments and the extraction of the optimal plane for the calculation of the distinctive thickness measurements. Then, the

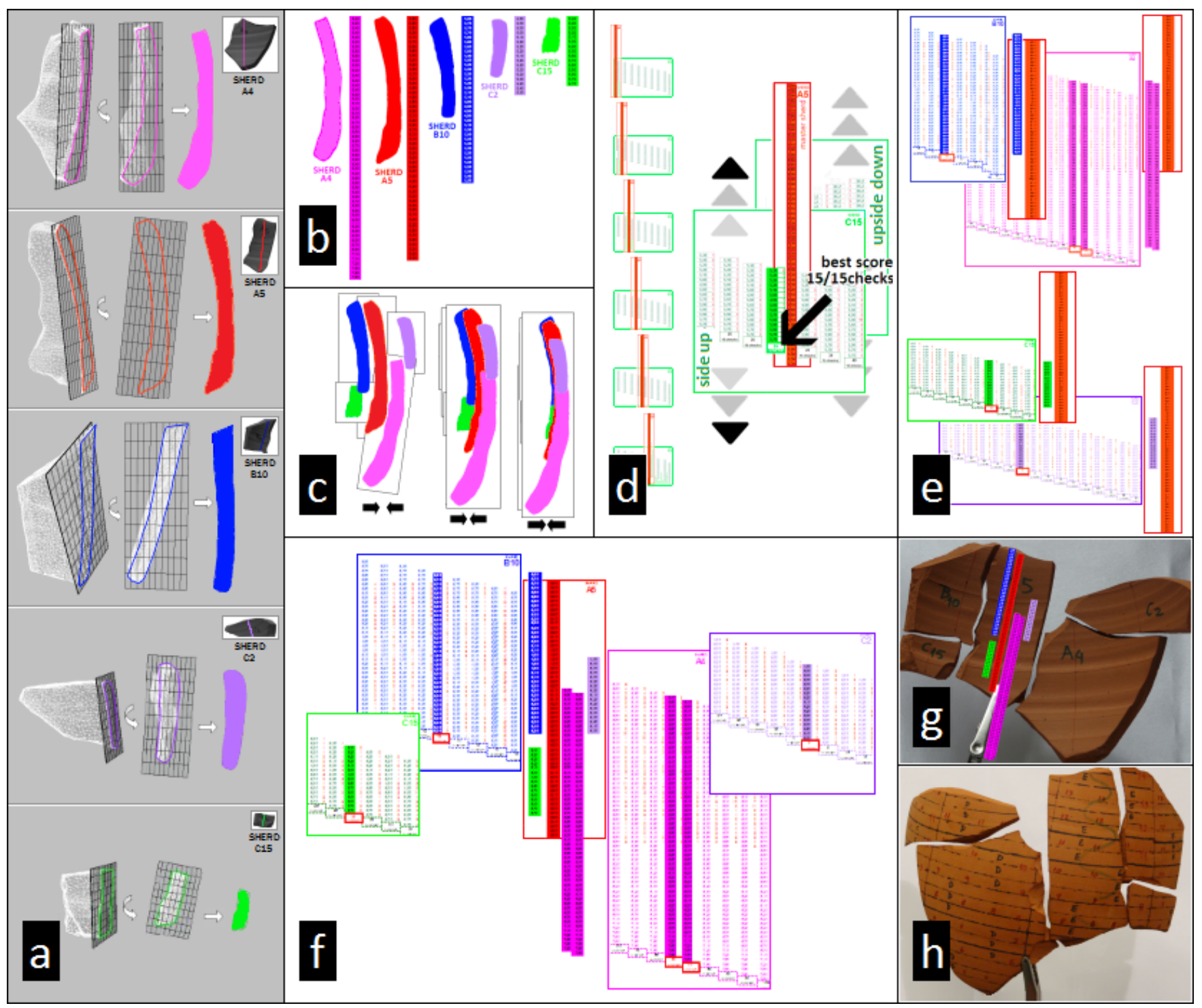

Figure 5. The five known neighbouring sherds, the five thickness profiles, the matching process and the results. 
3D software performs thickness sampling at a one-millimeter interval (Figure 3e) and the TP for each plane is then generated. Figure 5b, indicates all the acquired thickness measurements from the five sherds in this example. Using the repetitive procedure of section 3.3., the results confirm that our method allows the accurate reassembly of the five sherds with the minimal human interaction. Figure $5 \mathrm{f}$ and Figure $5 \mathrm{~g}$ show the effective matching of the five sherds in terms of selected planes and thickness profiles respectively. Finally, Figure $5 \mathrm{~h}$ presents the final reassembled external surface of the five assembled fragments. It should be noticed that the Thickness Profile method is effective even if some (or many) small pieces of the pottery are still missing. This has significant implications for archaeology since until now, manual reassembly is usually based on contour-based methods that exploit local surface characteristics on the fragments. However, if such small parts are missing or are altered, severe problems can emerge in the reassembly process.

\subsection{The special software and how a user should read the results}

In order to manage the thickness measurements we developed special software (25.293 lines of $\mathrm{C}++$ code) to perform all the necessary matching calculations. For each pair of sherds, our software provides a report in two pages - one of which in full graphics - including all the necessary information to guide the archaeologist (Figure 6). In essence, the software detects and prints out the exact matching point and the human interaction consists of correctly placing the "slave" fragment to the left or to the right of the master sherd. At the end of the process, the software provides a comprehensive page with information for all the sherds of the pottery. The most important information on the three report pages are found in two lines as marked and explained in Figure 7. The specific annotations refer to the top left checking pair (B2 vs A5) of sherds, shown in the table below Figure 11.

\subsection{Accuracy of the TP method and accuracy of measurements}

A critical point for the success of the TP method is the thickness precision with which the researcher [19], [20] can get the thickness of the available sherds. To our knowledge, the average thickness size of a sherd, usually lies between 2 and 15 $\mathrm{mm}$. These limits are fully confirmed on all the exhibits (sherds) held at the National Archaeological Museum in Athens, Greece. Our methodology requires discrimination capability of a hundredth of a millimeter $(0.01 \mathrm{~mm})$. In order to demonstrate the accuracy, we used a calliper (precision instrument used by the archaeologists) to manually capture the thickness of a

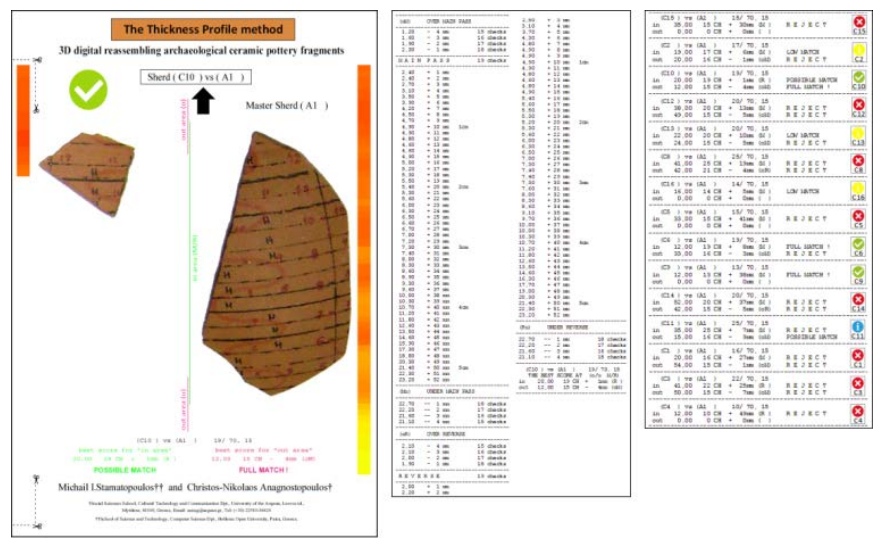

Figure 6. The 3 report pages. The comprehensive page, on the right.

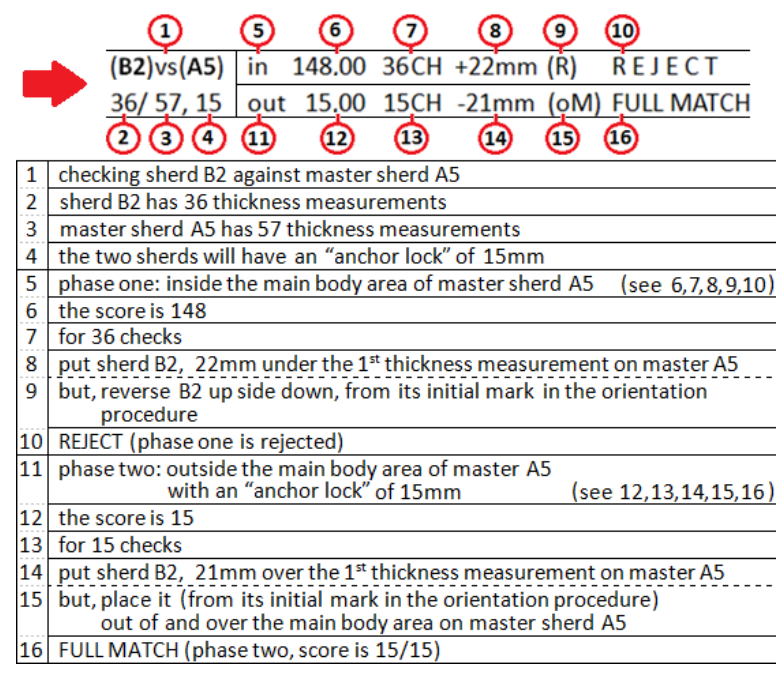

Figure 7. All the instructions for the two important lines.

specific sherd (i.e. B10). The measurements were then compared against those acquired using photogrammetry and 3D software. In Figure 8, on the left, the measurements using the calliper are displayed and on the right those acquired by photogrammetry. At both ends, left and right respectively, the corresponding colour map is illustrated (completely distinct and nearly identical).

\subsection{The "Dwarfs and the Giant" experiment}

During the reassembly of broken ceramic pottery, the available material also includes a proportion of small fragments which may have little identification information, thus complicating the reconstruction task. For this complex scenario, we have chosen to show the value of the TP method, on the ceramic replica was originally used for our experiment in Section 4.1. After being intentionally broken, our smashed pottery counted 15 small sherds $(12 \%)$ as displayed in Figure 9. Using the 31 report pages from the software (Figure 9 right) with the suggestions as displayed in the corresponding table, below Figure 10, each of the 15 small sherds ("Dwarfs") of the broken pottery was successfully placed against or deservedly rejected from the largest available sherd A1 ("Giant"). For the "Dwarfs and the Giant" experiment, we used all the available
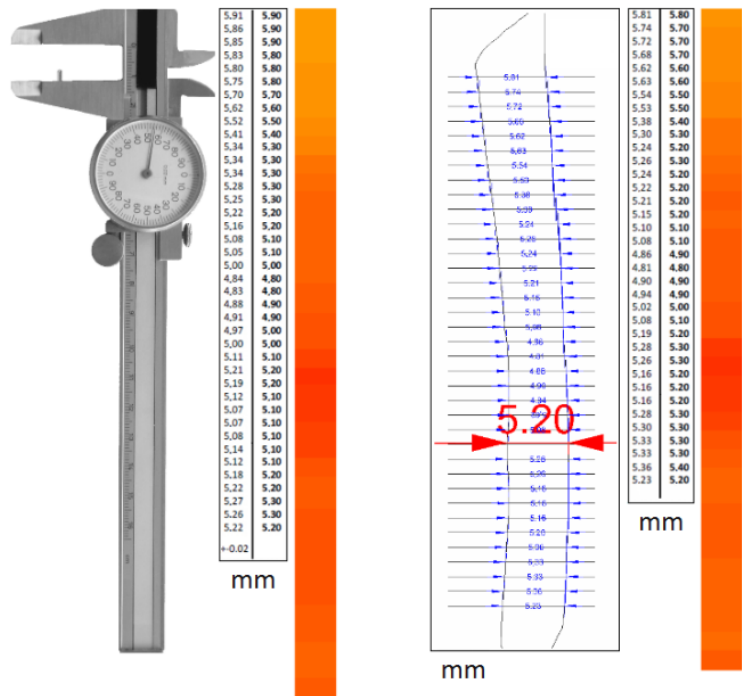

Figure 8. The accuracy and precision standards used. 

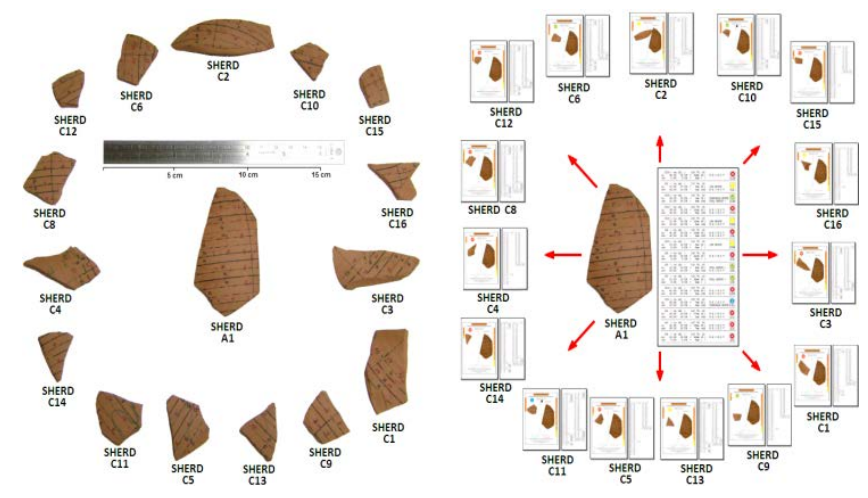

Figure 9. The 15 small sherds ("Dwarfs") against the "Giant". thickness measurements obtained from the previous processes. It should be emphasized that even for small sherds which are not matched up with the master sherd, the TP method manages to place them at the appropriate height based on the overall thickness profile or the thickness contour of the pottery under investigation. The 16 sherds $(15+1)$ used in the experiment, were placed on a metal mesh (model of the pottery) for demonstrating the potential and effectiveness of our method and its respective software (Figure 10).

\subsection{Effectiveness at $95 \%$}

Table 1 indicates all the acquired TPs of the 34 sherds belonging to the specific intentionally broken pottery. Figure 11 displays the successful reassembly of all the main wall sherds of the pottery body us a result of the highly successful suggestions

Table 1. The acquired TPs from the 34 pottery sherds.

\begin{tabular}{c|c|c|c|c}
\hline $\mathbf{A 1}$ & $\mathbf{A 2}$ & $\mathbf{A 3}$ & $\mathbf{A 4}$ & $\mathbf{A 5}$ \\
\hline 5.27 & 5.54 & 5.17 & 5.44 & 5.94 \\
5.35 & 5.62 & 5.10 & 5.56 & 5.94 \\
5.32 & 5.66 & 5.33 & 5.41 & 5.86 \\
5.25 & 5.54 & 5.83 & 5.44 & 5.80 \\
5.24 & 5.40 & 5.92 & 5.28 & 5.74 \\
5.23 & 5.30 & 5.96 & 5.34 & 5.73 \\
5.12 & 5.21 & 5.98 & 5.34 & 5.62 \\
5.11 & 5.25 & 5.98 & 5.46 & 5.46 \\
5.08 & 5.38 & 5.83 & 5.56 & 5.42 \\
5.14 & 5.90 & 5.64 & 5.36 & 5.38 \\
5.20 & 6.08 & 5.55 & 5.34 & 5.32 \\
5.22 & 6.04 & 5.48 & 6.33 & 5.23 \\
5.28 & 6.03 & 5.33 & 5.38 & 5.13 \\
5.39 & 5.98 & 5.33 & 5.44 & 5.01 \\
5.51 & 5.92 & 5.38 & 5.40 & 4.97 \\
5.41 & 5.88 & 5.58 & 5.40 & 4.83 \\
5.34 & 5.88 & 5.63 & 5.33 & 4.77 \\
5.32 & 6.01 & 5.59 & 5.26 & 4.81 \\
5.38 & 6.36 & 5.48 & 5.06 & 4.88 \\
5.45 & 6.48 & 5.28 & 4.99 & 4.95 \\
5.48 & 6.60 & 5.16 & 5.12 & 5.01 \\
5.50 & 6.63 & 5.18 & 5.80 & 5.12 \\
5.53 & 6.68 & 5.90 & 6.07 & 5.24 \\
5.57 & 6.73 & 5.99 & 5.98 & 5.22 \\
5.52 & 6.83 & 6.09 & 5.91 & 5.14 \\
5.43 & 6.85 & 6.15 & 5.88 & 5.10 \\
5.32 & 6.88 & 6.16 & 5.80 & 5.11 \\
5.26 & 6.93 & 6.18 & 5.70 & 5.18 \\
5.25 & 7.01 & 6.15 & 5.56 & 5.32 \\
5.25 & 7.58 & 6.15 & 5.56 & 5.30 \\
5.44 & 8.01 & 6.18 & 5.46 & 5.28 \\
5.70 & 8.29 & 6.25 & 5.37 & 5.30 \\
5.73 & 8.32 & 6.48 & 5.31 & 5.32 \\
5.57 & 8.58 & 6.70 & 5.37 & 5.28 \\
5.43 & 8.76 & 6.97 & 5.50 & 5.34 \\
5.38 & 9.05 & 7.04 & 5.57 & 5.21 \\
5.34 & 9.27 & 7.03 & 5.61 & 5.24 \\
5.46 & 9.43 & 7.08 & 5.36 & 5.27 \\
5.63 & 9.56 & 7.08 & 5.21 & 5.25 \\
5.82 & 9.69 & 7.14 & 5.14 & 5.26 \\
5.86 & 9.88 & 7.17 & 5.16 & 5.28 \\
5.82 & 10.06 & 7.14 & 5.86 & 5.20 \\
5.75 & 10.29 & 7.18 & 6.04 & 5.06 \\
5.59 & 10.66 & 7.20 & 6.01 & 5.01 \\
5.49 & 10.84 & 7.62 & 6.13 & 5.08 \\
5.36 & 10.88 & 7.90 & 6.18 & 5.52 \\
5.29 & 10.86 & 8.08 & 6.16 & 5.83 \\
5.37 & 10.80 & 8.38 & 6.16 & 6.07 \\
5.76 & 10.89 & 8.48 & 6.18 & 5.99 \\
6.00 & 11.58 & & 6.16 & 5.96 \\
5.99 & 12.28 & & 6.20 & 5.86 \\
5.96 & 12.53 & & 6.26 & 5.66 \\
5.93 & & & 6.34 & 5.54 \\
5.80 & & & 6.74 & 5.39 \\
5.74 & & & 6.94 & 5.33 \\
5.72 & & & 7.08 & 5.32 \\
5.79 & & & 7.13 & 5.32 \\
6.00 & & & 7.23 & \\
6.33 & & & 7.56 & \\
6.52 & & & 7.58 & \\
6.63 & & & 7.62 & \\
6.69 & & & & \\
6.73 & & & & \\
6.78 & & & & \\
6.83 & & & & \\
6.83 & & & & \\
6.85 & & & & \\
6.88 & & & & \\
6.94 & & & & $\mathrm{~mm}$ \\
& & & & \\
\hline & & & \\
& & & &
\end{tabular}

\begin{tabular}{|c|c|c|c|c|c|c|c|c|c|c|c|c|c|c|}
\hline B1 & B2 & B3 & B4 & B5 & B6 & B7 & B8 & B9 & B10 & B11 & B12 & B13 & B14 & - \\
\hline $\begin{array}{l}10.16 \\
10.68 \\
10.98 \\
11.28\end{array}$ & $\begin{array}{l}5.16 \\
5.34 \\
5.44 \\
5.53 \\
5.61 \\
5.61 \\
5.64 \\
5.67 \\
5.69 \\
5.72 \\
5.74 \\
5.80 \\
5.84 \\
5.86 \\
5.92 \\
5.96 \\
6.06 \\
6.06 \\
6.06 \\
6.07 \\
6.00 \\
5.98 \\
5.91 \\
5.88 \\
5.84 \\
5.78 \\
5.71 \\
5.61 \\
5.56 \\
5.51 \\
5.44 \\
5.41 \\
5.36 \\
5.32 \\
5.27 \\
5.24\end{array}$ & $\begin{array}{c}7.28 \\
7.53 \\
7.76 \\
8.17 \\
8.42 \\
8.56 \\
8.87 \\
9.05 \\
9.48 \\
9.60 \\
9.70 \\
9.80 \\
9.96 \\
10.08 \\
10.42 \\
10.72 \\
10.88 \\
10.95 \\
10.98 \\
11.06 \\
11.12 \\
11.28 \\
11.68 \\
12.08 \\
12.38 \\
12.78 \\
13.15 \\
13.38\end{array}$ & $\begin{array}{l}5.92 \\
5.92 \\
5.88 \\
5.92 \\
5.98 \\
5.98 \\
5.87 \\
5.81 \\
5.72 \\
5.72 \\
5.66 \\
5.56 \\
5.50 \\
5.45 \\
5.43 \\
5.35 \\
5.30 \\
5.21 \\
5.19 \\
5.14 \\
5.16 \\
5.20 \\
5.20 \\
5.21 \\
5.24 \\
5.17 \\
5.18 \\
5.31 \\
5.30 \\
5.31 \\
5.38 \\
5.58 \\
5.55 \\
5.50 \\
5.41 \\
5.36 \\
5.42 \\
5.45 \\
5.52 \\
5.54 \\
5.60\end{array}$ & $\begin{array}{l}5.26 \\
5.21 \\
5.03 \\
5.01 \\
5.11 \\
5.21 \\
5.82 \\
5.85 \\
5.87 \\
5.86 \\
5.78 \\
5.68 \\
5.58 \\
5.47 \\
5.41 \\
5.45 \\
5.55 \\
5.68 \\
5.87 \\
5.77 \\
5.62 \\
5.42 \\
5.38 \\
5.43 \\
6.09 \\
6.20 \\
6.22 \\
6.24 \\
6.21 \\
6.20 \\
6.18 \\
6.20 \\
6.28 \\
6.35 \\
6.45 \\
6.92 \\
6.95\end{array}$ & $\begin{array}{l}8.83 \\
8.44 \\
8.27 \\
7.95 \\
7.69 \\
7.48 \\
7.42 \\
7.31 \\
7.28 \\
7.25 \\
7.18 \\
6.96 \\
6.74 \\
6.46 \\
6.38 \\
6.35 \\
6.36 \\
6.35 \\
6.30 \\
6.30 \\
6.24 \\
6.20 \\
6.20 \\
6.13\end{array}$ & $\begin{array}{l}5.91 \\
5.99 \\
6.04 \\
6.00 \\
6.00 \\
6.02 \\
6.02 \\
6.02 \\
6.00 \\
6.00 \\
6.00 \\
5.99 \\
5.99 \\
5.94 \\
5.78 \\
5.64 \\
5.61 \\
5.62 \\
5.50 \\
5.40 \\
5.36 \\
5.26 \\
5.20 \\
5.14 \\
5.14 \\
5.16 \\
5.16 \\
5.22 \\
5.20 \\
5.18\end{array}$ & $\begin{array}{l}4.87 \\
4.91 \\
4.98 \\
5.02 \\
5.09 \\
5.12 \\
5.12 \\
5.14 \\
5.19 \\
5.24 \\
5.27 \\
5.31 \\
5.38 \\
5.44 \\
5.50 \\
5.51 \\
5.61 \\
5.64 \\
5.68 \\
5.73 \\
5.81 \\
5.81 \\
5.80 \\
5.78 \\
5.77 \\
5.75 \\
5.67 \\
5.58 \\
5.50 \\
5.47 \\
5.45 \\
5.38 \\
5.34 \\
5.32 \\
5.30 \\
5.24 \\
5.19\end{array}$ & $\begin{array}{l}5.94 \\
5.96 \\
5.90 \\
5.88 \\
5.82 \\
5.74 \\
5.66 \\
5.63 \\
5.66 \\
5.64 \\
5.54 \\
5.46 \\
5.38 \\
5.35 \\
5.27 \\
5.30 \\
5.24 \\
5.19 \\
5.22 \\
5.23 \\
5.23 \\
5.24 \\
5.19 \\
5.16 \\
5.11 \\
5.13 \\
5.15\end{array}$ & $\begin{array}{l}5.81 \\
5.74 \\
5.72 \\
5.68 \\
5.62 \\
5.63 \\
5.54 \\
5.53 \\
5.38 \\
5.30 \\
5.24 \\
5.26 \\
5.24 \\
5.22 \\
5.21 \\
5.15 \\
5.10 \\
5.08 \\
4.86 \\
4.81 \\
4.90 \\
4.94 \\
5.02 \\
5.08 \\
5.19 \\
5.28 \\
5.26 \\
5.16 \\
5.16 \\
5.16 \\
5.28 \\
5.30 \\
5.33 \\
5.33 \\
5.36 \\
5.23\end{array}$ & $\begin{array}{l}5.72 \\
5.54 \\
5.35 \\
5.30 \\
5.35 \\
5.48 \\
5.58 \\
5.70 \\
5.77 \\
5.81 \\
5.63 \\
5.23 \\
5.16 \\
5.12 \\
5.10 \\
5.28 \\
5.41 \\
5.53 \\
5.53 \\
5.54 \\
5.52 \\
5.44 \\
5.36 \\
5.34 \\
5.36 \\
5.48 \\
5.54\end{array}$ & $\begin{array}{l}5.44 \\
5.49 \\
5.52 \\
5.50 \\
5.44 \\
5.27 \\
5.18 \\
5.12 \\
5.16 \\
5.15 \\
5.24 \\
5.63 \\
5.70 \\
5.65 \\
5.53 \\
5.42 \\
5.31 \\
5.27 \\
5.29 \\
5.48 \\
5.66 \\
5.75 \\
5.77 \\
5.66 \\
5.58 \\
5.41 \\
5.32 \\
5.23 \\
5.23 \\
5.36 \\
5.92 \\
5.99 \\
5.92 \\
5.86 \\
5.80\end{array}$ & $\begin{array}{l}5.38 \\
5.29 \\
5.30 \\
5.32 \\
5.50 \\
5.54 \\
5.56 \\
5.34 \\
5.22 \\
5.19 \\
5.24 \\
5.67 \\
5.94 \\
6.09 \\
6.19 \\
6.31 \\
6.30 \\
6.30 \\
6.32 \\
6.33 \\
6.36 \\
6.35 \\
6.35 \\
6.41 \\
6.61 \\
6.79 \\
7.02 \\
7.04\end{array}$ & $\begin{array}{l}7.10 \\
7.12 \\
7.14 \\
7.23 \\
7.33 \\
7.38 \\
7.44 \\
7.50 \\
7.54 \\
7.91 \\
8.18 \\
8.48 \\
8.78 \\
8.86 \\
9.01 \\
9.34 \\
9.58 \\
9.81 \\
9.86 \\
9.88 \\
9.95 \\
10.02 \\
10.07 \\
10.76 \\
10.97 \\
11.22 \\
11.36\end{array}$ & $\mathrm{~mm}$ \\
\hline C1 & $\mathrm{C} 2$ & C3 & C4 & C5 & C6 & C8 & C9 & C10 & C11 & C12 & C13 & C14 & C15 & C16 \\
\hline $\begin{array}{l}5.21 \\
5.29 \\
5.31 \\
5.32 \\
5.36 \\
5.46 \\
5.50 \\
5.55 \\
5.63 \\
5.70 \\
5.73 \\
5.76 \\
5.81 \\
5.84 \\
5.78 \\
5.77\end{array}$ & $\begin{array}{l}4.94 \\
4.98 \\
4.96 \\
5.02 \\
5.07 \\
5.22 \\
5.23 \\
5.20 \\
5.13 \\
5.15 \\
5.21 \\
5.32 \\
5.32 \\
5.34 \\
5.46 \\
5.39 \\
5.31\end{array}$ & $\begin{array}{l}5.78 \\
5.79 \\
5.87 \\
5.87 \\
5.90 \\
5.91 \\
5.90 \\
5.82 \\
5.78 \\
5.75 \\
5.70 \\
5.67 \\
5.61 \\
5.57 \\
5.53 \\
5.47 \\
5.35 \\
5.28 \\
5.19 \\
5.18 \\
5.22 \\
5.24\end{array}$ & $\begin{array}{l}5.61 \\
5.65 \\
5.67 \\
5.75 \\
5.76 \\
5.83 \\
5.85 \\
5.83 \\
5.86 \\
5.89\end{array}$ & $\begin{array}{l}5.55 \\
5.74 \\
5.59 \\
5.46 \\
5.31 \\
5.22 \\
5.25 \\
5.38 \\
5.79 \\
5.98 \\
6.17 \\
6.25 \\
6.31 \\
6.36 \\
6.44\end{array}$ & $\begin{array}{l}4.89 \\
4.92 \\
4.97 \\
5.03 \\
5.09 \\
5.17 \\
5.38 \\
5.42 \\
5.38 \\
5.29 \\
5.33 \\
5.38 \\
5.52 \\
5.51 \\
5.54 \\
5.56 \\
5.54 \\
5.49 \\
5.39\end{array}$ & $\begin{array}{l}5.60 \\
5.73 \\
5.84 \\
5.75 \\
5.72 \\
5.67 \\
5.55 \\
5.48 \\
5.32 \\
5.23 \\
5.16 \\
5.17 \\
5.23 \\
5.46 \\
5.58 \\
5.49 \\
5.41 \\
5.20 \\
5.18 \\
5.21 \\
5.40 \\
5.84 \\
6.01 \\
6.15 \\
6.22\end{array}$ & $\begin{array}{l}5.44 \\
5.68 \\
5.86 \\
6.30 \\
5.84 \\
5.76 \\
5.66 \\
5.55 \\
5.43 \\
5.36 \\
5.47 \\
5.68 \\
6.01\end{array}$ & $\begin{array}{l}5.30 \\
5.27 \\
5.15 \\
5.15 \\
5.15 \\
5.18 \\
5.20 \\
5.15 \\
5.11 \\
5.10 \\
5.07 \\
5.00 \\
4.98 \\
5.03 \\
5.10 \\
5.15 \\
5.23 \\
5.42 \\
5.46\end{array}$ & $\begin{array}{l}4.96 \\
5.04 \\
5.11 \\
5.27 \\
5.36 \\
5.26 \\
5.18 \\
5.18 \\
5.28 \\
5.33 \\
5.37 \\
5.40 \\
5.44 \\
5.46 \\
5.39 \\
5.24 \\
5.21 \\
5.20 \\
5.23 \\
5.23 \\
5.20 \\
5.25 \\
5.35 \\
5.31 \\
5.21\end{array}$ & $\begin{array}{l}5.15 \\
5.15 \\
5.06 \\
4.94 \\
4.96 \\
5.10 \\
5.67 \\
5.81 \\
5.83 \\
5.83 \\
5.77 \\
5.71 \\
5.57 \\
5.47 \\
5.37 \\
5.30 \\
5.26 \\
5.31 \\
5.48 \\
5.60\end{array}$ & $\begin{array}{l}4.96 \\
5.08 \\
5.16 \\
5.33 \\
5.36 \\
5.26 \\
5.20 \\
5.25 \\
5.30 \\
5.42 \\
5.44 \\
5.42 \\
5.38 \\
5.39 \\
5.28 \\
5.21 \\
5.18 \\
5.20 \\
5.19 \\
5.14\end{array}$ & $\begin{array}{l}5.36 \\
5.28 \\
5.28 \\
5.36 \\
5.51 \\
5.56 \\
5.58 \\
5.43 \\
5.27 \\
5.19 \\
5.22 \\
5.34 \\
5.91 \\
5.98 \\
6.11 \\
6.17 \\
6.28 \\
6.28 \\
6.29 \\
6.35\end{array}$ & $\begin{array}{l}5.26 \\
5.20 \\
5.22 \\
5.21 \\
5.10 \\
4.96 \\
4.90 \\
5.02 \\
5.60 \\
5.72 \\
5.86 \\
5.86 \\
5.86 \\
5.72 \\
5.70\end{array}$ & $\begin{array}{l}4.89 \\
4.95 \\
5.03 \\
5.10 \\
5.29 \\
5.28 \\
5.19 \\
5.16 \\
5.17 \\
5.16 \\
5.30 \\
5.34 \\
5.33 \\
5.31\end{array}$ \\
\hline
\end{tabular}



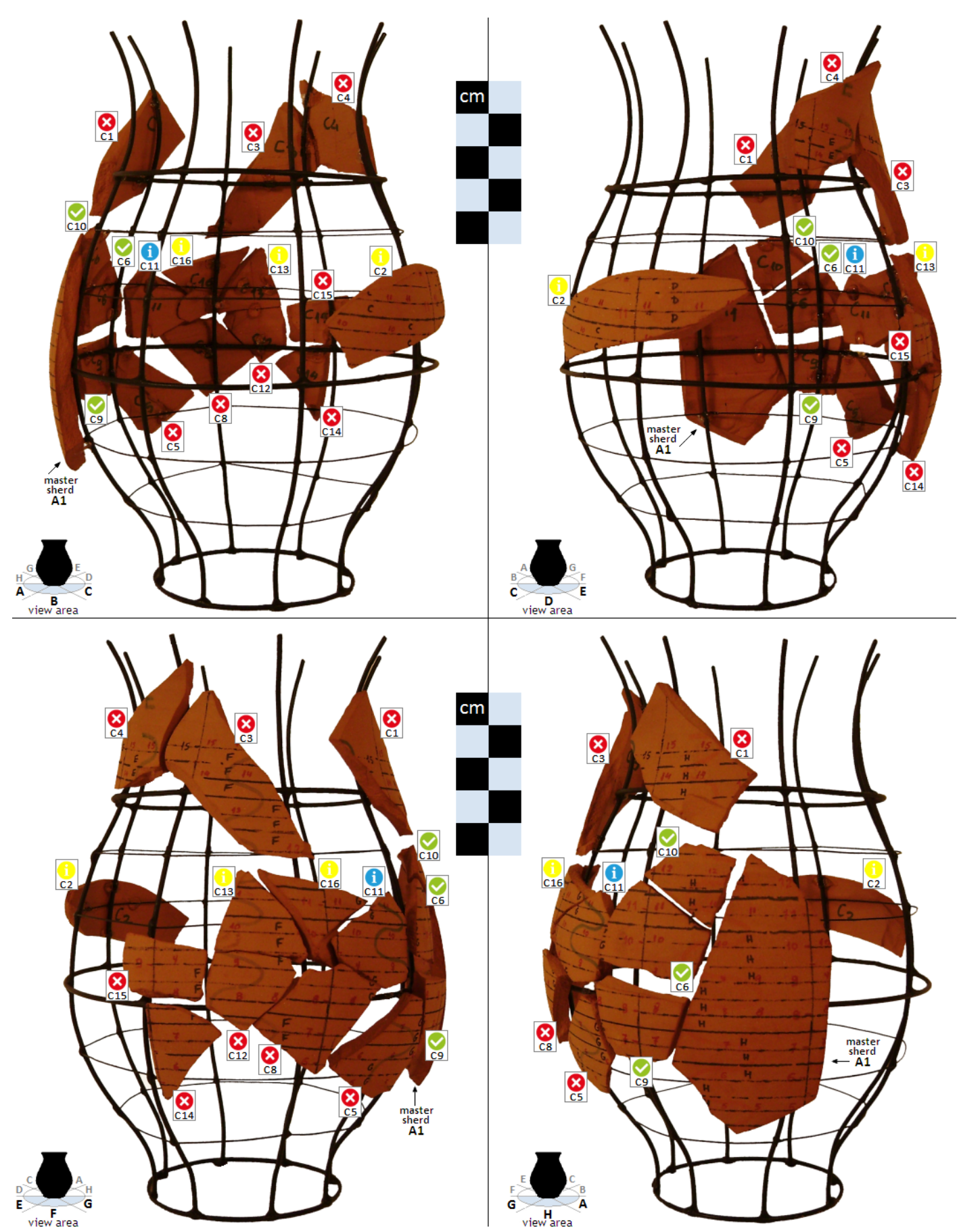

Figure 10. The optical results from the "Dwarfs and the Giant" experiment. The 15 small sherds against the largest sherd A1. Below, in table format, all the necessary information from the software for the guidance of the archaeologist. The suggestions for each pair.

\begin{tabular}{|c|c|c|c|}
\hline pair & sugge & sting position & annotatior \\
\hline $\begin{array}{l}\text { (C15) vs (A1) } \\
15 / 70,15\end{array}$ & $\begin{array}{lr}\text { in } & 35.00 \\
\text { out } & 0.00\end{array}$ & $\begin{array}{l}15 \mathrm{CH}+30 \mathrm{~mm}(\mathrm{M}) \\
0 \mathrm{CH}\end{array}$ & REJECT \\
\hline $\begin{array}{c}\text { (C2) vs (A1) } \\
17 / 70,15\end{array}$ & $\begin{array}{ll}\text { in } 19.00 \\
\text { out } 20.00\end{array}$ & $\begin{array}{ll}17 \mathrm{CH} & +6 \mathrm{~mm}(\mathrm{M}) \\
16 \mathrm{CH} & -1 \mathrm{~mm}(\mathrm{oM})\end{array}$ & $\begin{array}{l}\text { LOW MATCH } \\
\text { REJECT }\end{array}$ \\
\hline $\begin{array}{c}\text { (C10) vs (A1) } \\
19 / 70,15\end{array}$ & $\begin{array}{lr}\text { in } 20.00 \\
\text { out } 12.00 \\
\end{array}$ & $\begin{array}{ll}19 \mathrm{CH} & +1 \mathrm{~mm}(\mathrm{R}) \\
15 \mathrm{CH} & -4 \mathrm{~mm}(\mathrm{oM}) \\
\end{array}$ & $\begin{array}{l}\text { POSSIBLE MATCH } \\
\text { FULL MATCH! }\end{array}$ \\
\hline $\begin{array}{c}\text { (C12) vs (A1) } \\
20 / 70,15\end{array}$ & $\begin{array}{lr}\text { in } & 38.00 \\
\text { out } & 49.00 \\
\end{array}$ & $\begin{array}{l}20 \mathrm{CH}+13 \mathrm{~mm}(\mathrm{M}) \\
15 \mathrm{CH}-5 \mathrm{~mm}(\mathrm{oM})\end{array}$ & $\begin{array}{l}\text { REJECT } \\
\text { REJECT }\end{array}$ \\
\hline $\begin{array}{c}\text { (C13) vs (A1) } \\
20 / 70,15\end{array}$ & $\begin{array}{ll}\text { in } 22.00 \\
\text { out } 24.00\end{array}$ & $\begin{array}{l}20 \mathrm{CH}+10 \mathrm{~mm}(\mathrm{M}) \\
15 \mathrm{CH}-5 \mathrm{~mm}(\mathrm{oM})\end{array}$ & $\begin{array}{l}\text { LOW MATCH } \\
\text { REJ ECT }\end{array}$ \\
\hline $\begin{array}{c}\text { (C8) vs (A1) } \\
25 / 70,15\end{array}$ & $\begin{array}{lr}\text { in } 41.00 \\
\text { out } 42.00 \\
\end{array}$ & $\begin{array}{l}25 \mathrm{CH}+19 \mathrm{~mm}(\mathrm{M}) \\
21 \mathrm{CH} \quad-4 \mathrm{~mm}(\mathrm{oR})\end{array}$ & $\begin{array}{l}\text { REJECT } \\
\text { REJECT } \\
\end{array}$ \\
\hline $\begin{array}{c}\text { (C16) vs (A1) } \\
14 / 70,15\end{array}$ & $\begin{array}{lr}\text { in } & 16.00 \\
\text { out } & 0.00 \\
\end{array}$ & $\begin{aligned} & 14 \mathrm{CH}+5 \mathrm{~mm}(\mathrm{M}) \\
& 0 \mathrm{CH} \\
&\end{aligned}$ & LOW MATCH \\
\hline $\begin{array}{c}\text { (C5) vs (A1) } \\
15 / 70,15\end{array}$ & $\begin{array}{lr}\text { in } & 33.00 \\
\text { out } & 0.00 \\
\end{array}$ & $\begin{array}{l}15 \mathrm{CH}+41 \mathrm{~mm}(\mathrm{M}) \\
0 \mathrm{CH}\end{array}$ & REJECT \\
\hline
\end{tabular}

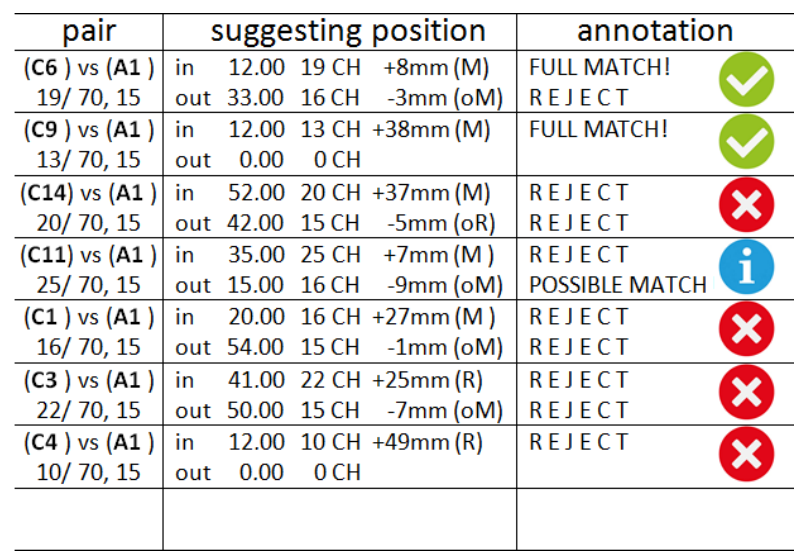




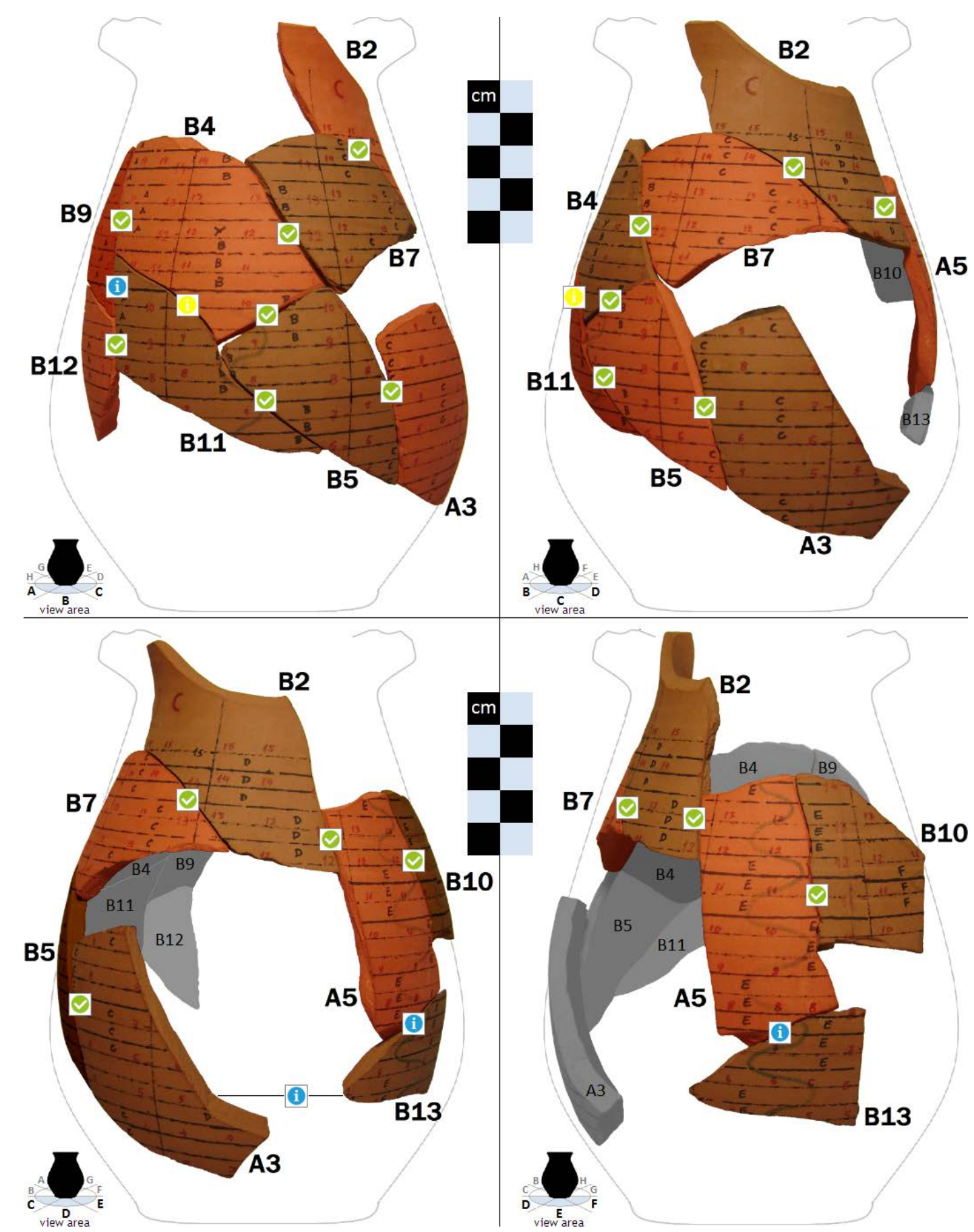

Figure 11. The optical results from the successful reassembly of all wall sherds. Below, in table format, all the necessary information from the software for the guidance of the archaeologist. The appropriate suggestion position for each matching pair.

\begin{tabular}{|c|c|c|}
\hline pair & suggesting position & annotation \\
\hline $\begin{array}{c}\text { (B2) vs (A5) } \\
36 / 57,15\end{array}$ & $\begin{array}{lrll}\text { in } 148.00 & 36 \mathrm{CH}+22 \mathrm{~mm}(\mathrm{R}) \\
\text { out } & 15.00 & 15 \mathrm{CH} & -21 \mathrm{~mm}(\mathrm{oM})\end{array}$ & $\begin{array}{l}\text { REJ E CT } \\
\text { FULL MATCH ! }\end{array}$ \\
\hline $\begin{array}{l}\text { (B5) vs (A3) } \\
37 / 49,15\end{array}$ & $\begin{array}{llll}\text { in } & 85.00 & 37 \mathrm{CH} & +1 \mathrm{~mm}(\mathrm{M}) \\
\text { out } & 42.00 & 35 \mathrm{CH} & -2 \mathrm{~mm}(\mathrm{oM}) \\
\end{array}$ & $\begin{array}{l}\text { RE J E C T } \\
\text { FULL MATCH ! }\end{array}$ \\
\hline $\begin{array}{c}\text { (B5) vs (B4) } \\
37 / 42,15\end{array}$ & $\begin{array}{lrll}\text { in } 165.00 & 37 \mathrm{CH} & +1 \mathrm{~mm}(\mathrm{R}) \\
\text { out } & 33.00 & 36 \mathrm{CH} & -26 \mathrm{~mm}(\mathrm{Mu})\end{array}$ & $\begin{array}{l}\text { RE J E C T } \\
\text { FULL MATCH ! }\end{array}$ \\
\hline $\begin{array}{c}\text { (B7) vs (B4) } \\
31 / 42,15\end{array}$ & $\begin{array}{llll}\text { in } & 58.00 & 31 \mathrm{CH} & +1 \mathrm{~mm}(\mathrm{M}) \\
\text { out } & 14.00 & 25 \mathrm{CH} & -6 \mathrm{~mm}(\mathrm{oM}) \\
\end{array}$ & $\begin{array}{l}\text { REJ E C T } \\
\text { FULL MATCH ! }\end{array}$ \\
\hline $\begin{array}{c}\text { (B7) vs (B2) } \\
31 / 36,15\end{array}$ & $\begin{array}{llll}\text { in } & 75.00 & 31 \mathrm{CH} & +6 \mathrm{~mm}(\mathrm{M}) \\
\text { out } & 15.00 & 30 \mathrm{CH} & -13 \mathrm{~mm}(\mathrm{Mu}) \\
\end{array}$ & $\begin{array}{l}\text { REJ J C T } \\
\text { FULL MATCH ! }\end{array}$ \\
\hline $\begin{array}{l}\text { (B9) vs (B4) } \\
27 / 42,15\end{array}$ & $\begin{array}{llll}\text { in } & 12.00 & 27 \mathrm{CH} & +3 \mathrm{~mm}(\mathrm{M}) \\
\text { out } & 30.00 & 26 \mathrm{CH} & -1 \mathrm{~mm}(\mathrm{oM}) \\
\end{array}$ & $\begin{array}{l}\text { FULL MATCH ! } \\
\text { FULL MATCH ! }\end{array}$ \\
\hline $\begin{array}{c}\text { (B10) vs (A5) } \\
36 / 57,15\end{array}$ & $\begin{array}{llll}\text { in } & 43.00 & 36 \mathrm{CH} & +1 \mathrm{~mm}(\mathrm{M}) \\
\text { out } & 37.00 & 34 \mathrm{CH} & -2 \mathrm{~mm}(\mathrm{oM}) \\
\end{array}$ & $\begin{array}{l}\text { FULL MATCH ! } \\
\text { FULL MATCH ! }\end{array}$ \\
\hline $\begin{array}{c}\text { (B11) vs (B4) } \\
27 / 42,15\end{array}$ & $\begin{array}{llll}\text { in } & 39.00 & 27 \mathrm{CH}+14 \mathrm{~mm}(\mathrm{R}) \\
\text { out } & 36.00 & 26 \mathrm{CH} & -28 \mathrm{~mm}(\mathrm{Mu})\end{array}$ & $\begin{array}{l}\text { LOW MATCH } \\
\text { LOW MATCH }\end{array}$ \\
\hline
\end{tabular}

\begin{tabular}{|c|c|c|}
\hline pair & suggesting position & annotation \\
\hline $\begin{array}{c}\text { (B11) vs (B12) } \\
27 / 35,15\end{array}$ & $\begin{array}{llll}\text { in } & 46.00 & 27 \mathrm{CH} & +5 \mathrm{~mm}(\mathrm{R}) \\
\text { out } & 19.00 & 21 \mathrm{CH} & -6 \mathrm{~mm}(\mathrm{oR})\end{array}$ & $\begin{array}{l}\text { R E J E C T } \\
\text { FULL MATCH! }\end{array}$ \\
\hline $\begin{array}{l}\text { (B11) vs (B5) } \\
27 / 37,15\end{array}$ & in $78.0027 \mathrm{CH}+1 \mathrm{~mm}(\mathrm{R})$ & $\begin{array}{l}\text { RE J E C T } \\
\text { FUM MATCHI }\end{array}$ \\
\hline $\begin{array}{c}\text { (B13) vs (A5) } \\
28 / 57,10\end{array}$ & 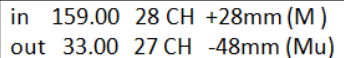 & $\begin{array}{l}\text { R E J E C T } \\
\text { POSSIBLE MATCH }\end{array}$ \\
\hline $\begin{array}{c}\text { (B13) vs (A3) } \\
28 / 49,15\end{array}$ & 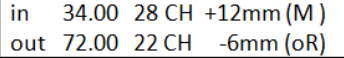 & $\begin{array}{l}\text { POSSIBLE MATCH } \\
\text { REJECT }\end{array}$ \\
\hline $\begin{array}{l}\text { (B9) vs (A1) } \\
27 / 70,15\end{array}$ & $\begin{array}{llll}\text { in } & 46.00 & 27 \mathrm{CH} & +6 \mathrm{~mm}(\mathrm{R}) \\
\text { out } & 13.00 & 15 \mathrm{CH} & -12 \mathrm{~mm}(\mathrm{oM})\end{array}$ & $\begin{array}{l}\text { R E J E C T } \\
\text { FULL MATCH ! }\end{array}$ \\
\hline $\begin{array}{c}\text { (B11) vs (B9) } \\
27 / 27,15\end{array}$ & $\begin{array}{llll}\text { in } & 69.00 & 27 \mathrm{CH} & +1 \mathrm{~mm}(\mathrm{M}) \\
\text { out } & 33.00 & 26 \mathrm{CH} & -12 \mathrm{~mm}(\mathrm{Mu})\end{array}$ & $\begin{array}{l}\text { R E J E C T } \\
\text { POSSIBLE MATCH }\end{array}$ \\
\hline $\begin{array}{c}\text { (B12) vs (A1) } \\
35 / 70,15\end{array}$ & $\begin{array}{l}\text { in } 37.0035 \mathrm{CH}+20 \mathrm{~mm}(\mathrm{M}) \\
\text { out } 23.0017 \mathrm{CH}-18 \mathrm{~mm}(\mathrm{oR})\end{array}$ & $\begin{array}{l}\text { FULL MATCH ! } \\
\text { POSSIBLE MATCH }\end{array}$ \\
\hline
\end{tabular}


by the software as displayed in the corresponding table, below Figure 11. Eventually the handmade pottery was fully digitally reassembled successfully by the TP method, achieving an effective surface coverage of $95 \%$ over the available 34 pottery sherds (five originally sherds in Figure $5 \mathrm{~h}$, fifteen very small sherds in Figure 10 and twelve wall sherds in Figure 11).

\section{WORKING WITH REAL POTTERY FROM THE PAST}

In this section we demonstrate the Thickness Profile method on a real ancient pottery. As the method is effective even if some (or many) small-sized pieces of the pottery are still missing or some of the sherds has been damaged (i.e. there is a "damages gap" inside the broken side surfaces) this real theme is ideal to show the benefits of the new method. Any other

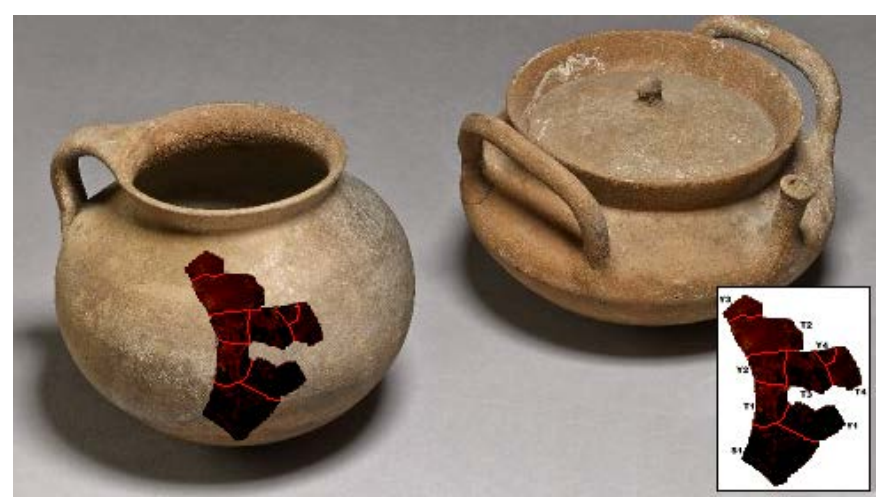

Figure 12. Two complete Lopas is illustrated [21].

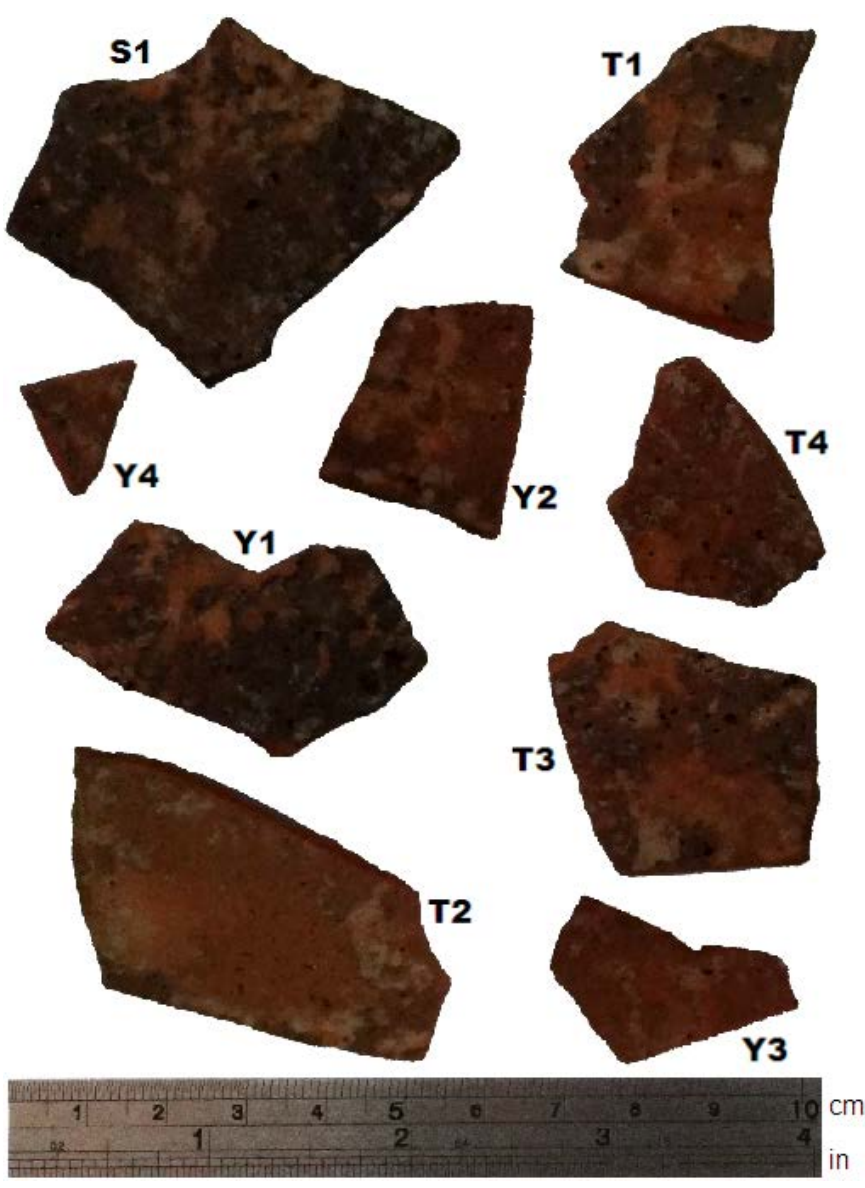

Figure 13. The nine thin sherds from Lopas (400 B.C.). method based on external characteristics will probably fail.

We investigate an unpainted real ancient ceramic pottery from 400 B.C., probably a Lopas (Figure 12), which is an unglazed cooking pottery (chytra). The nine small Lopas sherds (Figure 13), came from an excavation, very close to a coast near Athens, Greece. Some sherds of the ceramic pottery have severe wear. Figure 14 demonstrates the various views of sherds at the orientation procedure, the acquired $3 \mathrm{D}$ models and the extraction of the optimal plane for the calculation of the distinctive thickness measurements. Table 2 indicates all the thickness measurements from the sherds in this example. Figure 15 presents the final reassembled external surface obtained out of nine assembled fragments.

Sherds T3 and Y1 have a local "bump" (swelling area) as marked in Figure 15 (right) (perhaps by the presence of a hole or a handle) and therefore cannot easily be matched up with others. Even in this very difficult case with very small and some damaged fragments, our method achieved very satisfactory results, as displayed in the corresponding table, below Figure 15. The results confirm that our method allows the accurate reassembly of the nine sherds to be achieved with minimal human interaction. The special software applied indicates the best matching point and the human interaction is limited to placing correctly the fragments chosen by the method to the left or to the right of the driver sherd.

It should be noted that our software has also the ability to automatically find the correct side-up position (while sorting the number sequence) for each sherd, so it is not necessary to allow for and mark the correct side-up position for each sherd during the alignment process with the crosshair beam lasers. Simply put, in a worst-case scenario, the Thickness Profile method will guide the archaeologist/user to get the entire reassembled pottery upside down (if not side-up).

Table 2. The acquired TPs from Lopas. The "bump" in yellow.

\begin{tabular}{|c|c|c|c|c|c|c|c|c|}
\hline S1 & T1 & T2 & T3 & T4 & Y1 & Y2 & Y3 & Y4 \\
\hline 3.52 & 3.57 & 2.82 & 3.13 & 2.98 & 4.16 & 3.40 & 2.70 & 3.23 \\
\hline 3.57 & 3.62 & 2.88 & 3.17 & 3.08 & 4.13 & 3.45 & 2.68 & 3.27 \\
\hline 3.58 & 3.64 & 2.93 & 3.20 & 3.13 & 4.10 & 3.50 & 2.73 & 3.20 \\
\hline 3.52 & 3.63 & 2.94 & 3.24 & 3.17 & 4.11 & 3.41 & 2.76 & 3.22 \\
\hline 3.54 & 3.64 & 2.96 & 3.30 & 3.21 & 4.07 & 3.42 & 2.77 & 3.28 \\
\hline 3.51 & 3.67 & 2.99 & 3.38 & 3.27 & 4.08 & 3.40 & 2.75 & 3.28 \\
\hline 3.47 & 3.68 & 3.02 & 3.40 & 3.31 & 4.09 & 3.37 & 2.75 & 3.30 \\
\hline 3.45 & 3.69 & 3.08 & 3.42 & 3.36 & 4.10 & 3.38 & 2.75 & 3.34 \\
\hline 3.45 & 3.66 & 3.04 & 3.48 & 3.40 & 4.12 & 3.37 & 2.75 & 3.38 \\
\hline 3.38 & 3.68 & 3.07 & 3.54 & 3.43 & 4.12 & 3.38 & 2.78 & 3.40 \\
\hline 3.43 & 3.67 & 3.13 & 3.55 & 3.48 & 4.13 & 3.37 & 2.78 & 3.39 \\
\hline 3.43 & 3.63 & 3.13 & 3.59 & 3.47 & 4.16 & 3.38 & 2.77 & 3.45 \\
\hline 3.44 & 3.61 & 3.15 & 3.61 & 3.43 & 4.16 & 3.37 & 2.78 & \\
\hline 3.38 & 3.62 & 3.16 & 3.66 & 3.41 & 4.10 & 3.36 & 2.78 & \\
\hline 3.37 & 3.61 & 3.17 & 3.70 & 3.39 & 4.07 & 3.34 & 2.76 & \\
\hline 3.36 & 3.56 & 3.16 & 3.76 & 3.45 & & 3.34 & & \\
\hline 3.40 & 3.54 & 3.20 & 3.78 & 3.47 & & 3.38 & & \\
\hline 3.41 & 3.50 & 3.21 & 3.81 & 3.46 & & 3.39 & & \\
\hline 3.40 & 3.47 & 3.23 & 3.81 & 3.49 & & 3.41 & & \\
\hline 3.40 & 3.46 & 3.28 & 3.84 & 3.44 & & & & \\
\hline 3.40 & 3.44 & 3.30 & 3.86 & 3.48 & & & & \\
\hline 3.41 & 3.43 & 3.31 & 3.89 & 3.49 & & & & \\
\hline 3.44 & 3.44 & 3.31 & 3.94 & 3.52 & & & & \\
\hline 3.43 & 3.42 & 3.36 & 3.98 & 3.55 & & & & \\
\hline 3.46 & 3.44 & 3.38 & 4.01 & 3.57 & & & & \\
\hline 3.52 & 3.45 & & 4.14 & & & & & \\
\hline 3.47 & 3.43 & & & & & & & \\
\hline 3.48 & 3.46 & & & & & & & \\
\hline 3.50 & 3.48 & & & & & & & \\
\hline 3.49 & 3.50 & & & & & & & \\
\hline 3.50 & 3.50 & & & & & & & \\
\hline 3.47 & 3.50 & & & & & & & \\
\hline 3.44 & 3.54 & & & & & & & \\
\hline 3.45 & 3.56 & & & & & & & \\
\hline 3.42 & 3.54 & & & & & & & \\
\hline 3.43 & 3.55 & & & & & & & \\
\hline 3.42 & 3.54 & & & & & & & \\
\hline 3.40 & & & & & & & & \\
\hline 3.38 & & & & & & & & $\mathrm{~mm}$ \\
\hline
\end{tabular}




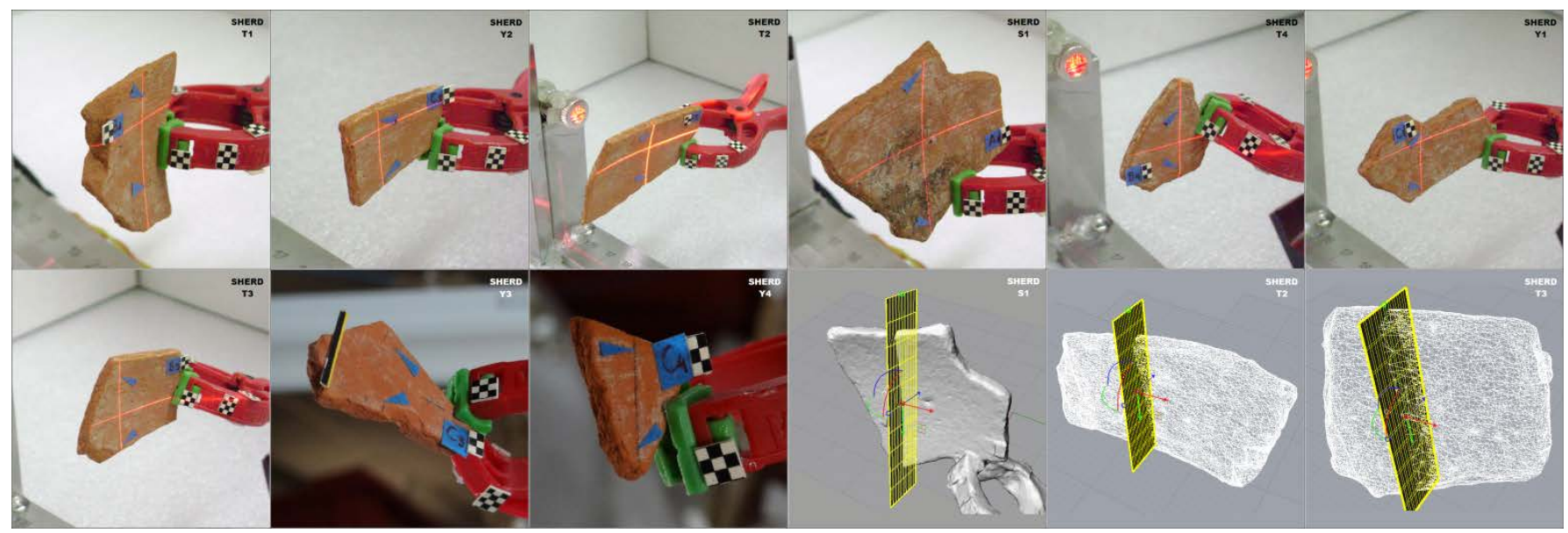

Figure 14. Multiple views of sherds at the orientation procedure and the extraction of their optimal thickness profiles (TPs).

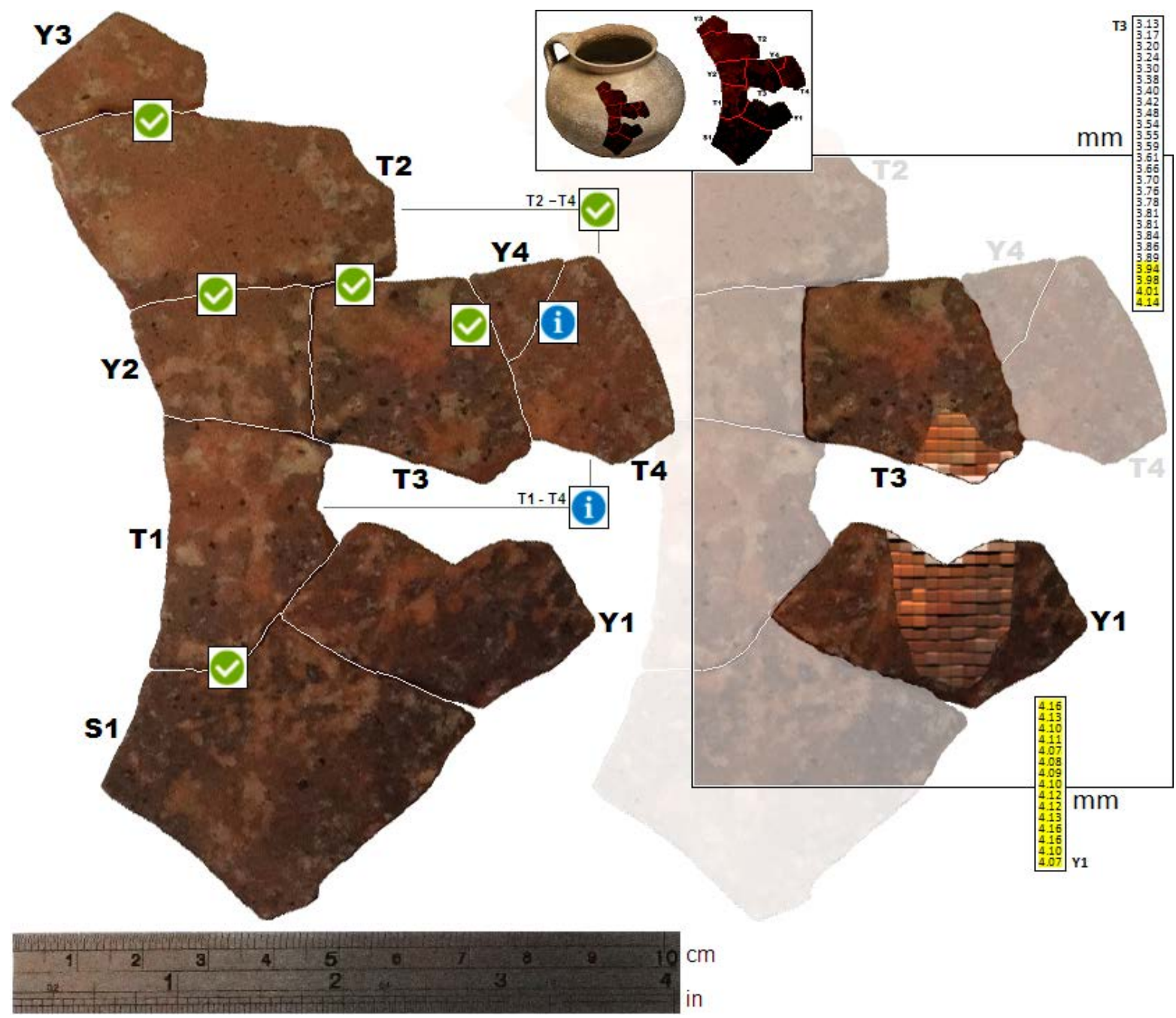

Figure 15. The reassembled external surface of Lopas. Below in a table format all the necessary information from the software. On the right the "bump" (swelling area) on the material (perhaps by the presence of a hole or a handle).

\begin{tabular}{|c|c|c|}
\hline pair & suggesting position & annotation \\
\hline $\begin{array}{l}\text { (Y3) vs (T2) } \\
15 / 25,5\end{array}$ & $\begin{array}{lrrrr}\text { in } & 38.00 & 15 \mathrm{CH} & +1 \mathrm{~mm}(\mathrm{M}) \\
\text { out } & 5.00 & 5 \mathrm{CH} & -10 \mathrm{~mm}(\mathrm{oM})\end{array}$ & $\begin{array}{l}\text { REJ JCT } \\
\text { FULL MATCH! }\end{array}$ \\
\hline $\begin{array}{l}\text { (T1) vs (S1) } \\
37 / 39,15\end{array}$ & 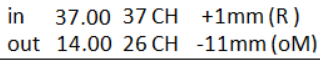 & $\begin{array}{l}\text { REJECT } \\
\text { FULL MATCH! }\end{array}$ \\
\hline $\begin{array}{l}\text { (T4) vs (T1) } \\
25 / 37,5\end{array}$ & 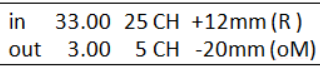 & $\begin{array}{l}\text { RE J E C T } \\
\text { POSSIBLE MATCH }\end{array}$ \\
\hline $\begin{array}{l}\text { (T4) vs (T2) } \\
25 / 25,5\end{array}$ & $\begin{array}{lrll}\text { in } & 64.00 & 25 \mathrm{CH} & +1 \mathrm{~mm}(\mathrm{M}) \\
\text { out } & 6.00 & 24 \mathrm{CH} & -16 \mathrm{~mm}(\mathrm{Mu})\end{array}$ & $\begin{array}{l}\text { REJECT } \\
\text { FULL MATCH! }\end{array}$ \\
\hline
\end{tabular}

\begin{tabular}{|c|c|c|c|c|}
\hline pair & sugge & sting & position & annotatio \\
\hline $\begin{array}{c}\text { (Y4) vs (T4) } \\
12 / 25,5\end{array}$ & $\begin{array}{ll}\text { in } & 8.00 \\
\text { out } & 7.00\end{array}$ & $\begin{array}{l}12 \mathrm{CH} \\
11 \mathrm{CH}\end{array}$ & $\begin{array}{l}+1 \mathrm{~mm}(\mathrm{M}) \\
-1 \mathrm{~mm}(\mathrm{oM})\end{array}$ & $\begin{array}{l}\text { RE J ECT } \\
\text { POSSIBLE MATCH }\end{array}$ \\
\hline $\begin{array}{l}\text { (Y4) vs (T3) } \\
12 / 26,5\end{array}$ & $\begin{array}{l}\text { in } 10.00 \\
\text { out } 4.00\end{array}$ & $\begin{array}{r}12 \mathrm{CH} \\
9 \mathrm{CH}\end{array}$ & $\begin{array}{l}+1 \mathrm{~mm}(\mathrm{M}) \\
-3 \mathrm{~mm}(\mathrm{oM})\end{array}$ & $\begin{array}{l}\text { RE J E C T } \\
\text { FULL MATCH! }\end{array}$ \\
\hline $\begin{array}{l}\text { (T3) vs (T2) } \\
26 / 25,5\end{array}$ & $\begin{array}{ll}\text { in } & 0.00 \\
\text { out } & 4.00\end{array}$ & $\begin{array}{l}26 \mathrm{CH} \\
25 \mathrm{CH}\end{array}$ & $\begin{array}{l}+0 \mathrm{~mm}(\text { ) } \\
-18 \mathrm{~mm}(\mathrm{Mu})\end{array}$ & FULL MATCH! \\
\hline $\begin{array}{c}\text { (Y2) vs (T2) } \\
19 / 25,5\end{array}$ & $\begin{array}{l}\text { in } 38.00 \\
\text { out } 5.00\end{array}$ & $\begin{array}{l}19 \mathrm{CH} \\
18 \mathrm{CH}\end{array}$ & $\begin{array}{c}+7 \mathrm{~mm}(\mathrm{M}) \\
-21 \mathrm{~mm}(\mathrm{Mu})\end{array}$ & $\begin{array}{l}\text { RE J E C T } \\
\text { FULL MATCH! }\end{array}$ \\
\hline
\end{tabular}




\section{CONCLUSIONS}

We have presented a new digital approach for reassembling ancient ceramic pottery based on 3D models of their fragments and the exploitation of their thickness profile. The results show that our method allows for accurate reassembly to be achieved with minimal human interaction. The method is based on thickness, which is some king of information encapsulated in the inner part of ostraca that cannot be affected by harsh environmental conditions. Our method was verified on real and synthetic pottery. Using photogrammetry, 3D representations and precise measurements, we have demonstrated the validity of the new suggested method. To our knowledge, we have introduced a completely new way of bridging the gap between top-down and bottom-up approaches to the issue and what is more, it answers difficult problems in the excessively time consuming task of manual reassembly of ancient pottery. We intend to expand and fine-tune our methodology with more complex experiments using real archaeological potteries from museum collections in countries with high archaeological interest (especially on themes from Archaic, Classical or Hellenistic period).

\section{ACKNOWLEDGEMENT}

The authors would like to thank the Hellenic Ephorate of Antiquities of West Attika, Piraeus and Islands, the Archaeological Museum of Piraeus and the laboratories at Hellinicon for their archaeological support. Furthermore we would like to thank the curator Mrs. Stella Xrisoulaki, head of conservation department Mrs. Aikaterini Panagopoulou, the conservator Mr. Lazaros Valsamis and the conservator Mrs. Maria Venetsanopoulou. Special thanks for the valuable assistance to excavator and archaeologist Mrs. Mairy Giamalidi.

\section{REFERENCES}

[1] M.Kampel, R.Sablatnig, H.Mara, "Robust 3D reconstruction of archaeological pottery based on concentric circular rills", in: Magnenat-Thalmann, N., Rindel, J.H. (Eds.), The 6th International Workshop on Image Analysis for Multimedia Interactive Services, Montreux, Switzerland, 2005, pp.14-20.

[2] R.Sablatnig, C.Menard, "3D Reconstruction of archaeological pottery using profile primitives", Proceeding of the International Workshop on Synthetic-Natural Hybrid Coding and 3D Imaging, Rhodes, Greece, September 1997, pp.93-96.

[3] M.Kampel, R.Sablatnig, "Detection of matching fragments of pottery", Computer Applications and Quantitative Methods in Archaeology, Beyond the artifact digital interpretation of the past, Prato, Italy, April 2004.

[4] M.Kampel, R.Sablatnig, "Profile-based pottery reconstruction", IEEE, Proceedings of Conference on Computer Vision and Pattern Recognition Workshop, Wisconsin, U.S.A., June 2003, pp.1-6.

[5] G.Papaioannou, E.A.Karabassi, "On the automatic assemblage of arbitrary broken solid artefacts", Image and Vision Computing, Elsevier, vol.21, is.5, May 2003, pp.401-412.
[6] M.Kampel, H.Mara, R.Sablatnig, "Automated investigation of archaeological vessels", 14th European Signal Processing Conference, EUSIPCO 2006, Florence, Italy, September 2006.

[7] D.Filippas, A.Georgopoulos, "Development of an algorithmic procedure for the detection of conjugate fragments", XXIV International CIPA Symposium, Strasbourg, France, September 2013.

[8] M.Kampel, F.J.Melero, "Virtual vessel reconstruction from a fragment's profile", 4th International Symposium on Virtual Reality, Archaeology \& Intelligent Cultural Heritage, VAST 2003, Brighton, United Kingdom, 2003.

[9] I.Marie, H.Qasrawi, "Virtual assembly of pottery fragments using moire surface profile measurements", Journal of Archaeological Science, vol.32, is.10, October 2005, pp.1527-1533.

[10] G.Papaioannou, E.A.Karabassi, T.Theoharis, "Virtual archaeologist: assembling the past", IEEE Computer Graphics and Applications, vol.21, no.2, March-April 2001, pp.53-59.

[11] G.Papaioannou, E.A.Karabassi, T.Theoharis, "Reconstruction of three-dimensional objects through matching of their parts", IEEE transactions on pattern analysis and machine intelligence, vol.24, no.1, January 2002, pp.114-124.

[12] G.Papaioannou, T.Theoharis, "Fast fragment assemblage using boundary line and surface matching", Conference: Computer Vision and Pattern Recognition Workshop, vol.1, Wisconsin, U.S.A., June 2003.

[13] N.A.Rasheed, M.J.Nordin, "A survey of computer methods in reconstruction of 3D archaeological pottery objects", International Journal of Advanced Research, vol.3, is.3, January 2015, pp.712-714.

[14] A.Karasik, U.Smilansky, "3D scanning technology as a standard archaeological tool for pottery analysis: practice and theory", Journal of Archaeological Science, vol.35, is.5, May 2008, pp.1148-1168.

[15] K.Son, E.B.Almeida, D.B.Cooper, "Axially symmetric 3D pots configuration system using axis of symmetry and break curve", Computer Vision and Pattern Recognition, 2013 IEEE Conference, Oregon, U.S.A., June 2013, pp.257-264.

[16] Q.X.Huang, S.Flory, N.Gelfand, M.Hofer, H.Pottmann, "Reassembling fractured objects by geometric matching", ACM Transactions on Graphics, vol.25, is.3, N.Y., U.S.A., July 2006, pp.569-578.

[17] A.R.Willis, D.B.Cooper, "Bayesian assembly of 3D axially symmetric shapes from fragments", Conference on Computer Vision and Pattern Recognition, vol.1, Washington, U.S.A., June 2004, pp.82-89.

[18] S.Toby, Athenian Vase Construction: A Potter's Analysis, California: The J.Paul Getty Museum, 1999, ISBN 978-0-89236466-4.

[19] I.Giannoukos, C.N.Anagnostopoulos, E.Kayafas, V.Loumos, "Dental measurements using 3D models of plaster imprints", 17th Symposium IMEKO TC4 and 15th International Workshop, Kosice, Slovakia, September 2010, pp.466-471.

[20] A.Gomez-Gutierrez, J.J.Sanjose-Blasco, J.Matias-Bejarano, F.Berenguer-Sempere, "Comparing two photo-reconstruction methods to produce high density point clouds and DEMs in the Corral del Veleta Rock Glacier", Remote Sensing, 6(6), Spain, 2014, pp.5407-5427.

[21] A Lopas image: available online at: http://www.britishmuseum.org/research/collection_online/coll ection_object_details/collection_image_gallery.aspx?partid=1\&a ssetid $=1594884001$ \&objectid $=3309459$. 